\title{
A Feminist Analysis of Mr. and Mrs. Dove by Katherine Mansfield
}

\author{
LIU Xi, HUANG Xin \\ Changchun University, Changchun, China
}

\begin{abstract}
Katherine Mansfield (1888-1923), a New Zealand's celebrated short story writer, was famous for her exquisite portrayals of women and she made great contribution to the British short story as well. Greatly influenced by Anton Chekhov, her writing firmly fixed on the small details of human behavior. She created her best works in the early 1920s, and her book, The Garden Party, arrived at the peak of great achievement. Set in England, her short story, Mr. and Mrs. Dove, described a story about the man's last day in England and a series of things that happened to his visit to his beloved woman's home which presented the relationships between his mom and him, and his beloved woman and him. This paper mainly explores the feminist thoughts of the female characters. The paper concludes that the awakening awareness of women in this story was obviously from the perspectives of striking against the patriarchal system and Mansfield was actually a feminist pioneer who promoted the development of feminism in the whole world.
\end{abstract}

Keywords: feminism, authority, rebellion, independence

\section{Introduction}

Katherine Mansfield's works often focus on the inner sensations of women, and she was skilled at sketching the mental activities of the women roles. To some extent, she became the representative writer on the academic field of feminism. And the reason why she emphasized the characters' inner worlds was that she suffered a lot from her marriages. What is more, she was greatly influenced by Anton Chekhov, sharing his warm humanity and attention to small details of human behaviors. Mansfield created her best work in the early 1920s, and some of her most well-known stories are The Garden Party, The Daughters of the Late Colonel, and The Fly. Undoubtedly, her influence on the development of the modern short story as a form of literature was remarkable. Set in England, her book Mr. and Mrs. Dove mainly depicted what happened between a man named Reggie and a young lady named Anne. This story took place in Reggie's last day in England, and he intended to go to Anne's house to say goodbye to her, and offer the "secret" to her. After coming across mom and answering mom's few questions, Reggie left home and stepped towards Anne's home. Surprisingly, there was Anne alone at home. After a free talking, Anne asked him to say goodbye to her pet doves. The two doves were walking at their "oasis”, however, Mr. Dove was always running after Mrs. Dove. But Reggie paid no

LIU Xi, M.A., Lecturer, School of Foreign Languages, Changchun University.

HUANG Xin, Undergraduate, School of Foreign Languages, Changchun University. 
attention to the two doves, at that moment he was hesitant to expose his secret out of himself. However, when he was brave enough to talk his heart out, Anne rejected him mercilessly. Then, Reggie had to determine to leave. Though Anne explained a lot to him, Reggie insisted on leaving, and then he went away resolutely. Unexpectedly, Anne finally asked him to come back which means she agreed to marry him.

And how did the female characters reveal their feminist thoughts? This paper analyzes the personalities of the three female characters to manifest their feminist thoughts and their rebellion against the traditional patriarchy.

\section{Domestic Authority of Mom}

Mansfield was gifted at sketching roles’ characters by using minor plots. In Mr. and Mrs. Dove, Reggie, a man who was living with his Mom, had already lost man's traditional authority. Whatever he did or wherever he went, his Mom must be well-known of it. Some details that Mom involved showed the weakness in Reggie's character, which in other words emphasized the strength of the Mom.

At the beginning of the story, after a delicate dressing, Reggie took out his cigarette case, "but remembering how the mater hated him to smoke in his bedroom, put it back again and drifted over to the chest of drawers" (Mansfield, 2008, p. 231). Conspicuously, Reggie was a pious son who obeyed the rules made by Mom. And Mom's words were so important that he couldn't rebel against them. "she had quarreled with all her own and the governor's relations before Reggie had won his first trouser pocket” (Mansfield, 2008, p. 232), the woman was a capable, powerful Mom who could do everything to satisfy her son. Besides, whenever Reggie went far from home and felt homesick, once he heard the gramophone cried: "Dear, what is life but love?" "His only vision was of the mater, tall and stout, rustling down the garden path, with Chinny and Biddy at her heels...” (Mansfield, 2008, p. 232). After a long time dominating her son, the Mom had already established a deep connection with Reggie, as described "she was positively all that he had" (Mansfield, 2008, p. 232), undoubtedly, she steadily became the center of his life. What is more, Mom's pet dogs and the scissors also underscored his weak character.

The two dogs were Chinny and Biddy, and they were always at Mom's heel. When Reggie was about to leave for Anne's home, he came upon Mom and the two dogs. Facing the questions given by Mom "you are not going out, Reginald?” (Mansfield, 2008, p. 233), “where are you going, if your mother may ask?” (Mansfield, 2008, p. 233), Reggie didn’t tell her truth but replied with a few vague words. Thus, in Reggie's mind, the two dogs understand every word of Mom and they are more loyal than him. It clearly revealed that Reggie felt guilty of not being honest to Mom. Hearing the conversation between Reggie and hostess, "Biddy lay down with her tongue poked out; she was so fat and glossy she looked like a lump of half-melted toffee. But Chinny’s porcelain eyes gloomed at Reggie” (Mansfield, 2008, p. 233), the two dogs' actions respectively showed that Reggie, on the one hand, wanted to keep allegiance to Mom just like the docile Biddy, while on the other hand, he desired to pursue his own life without mom's interference, but it's too difficult to achieve, thus, he was as gloomed as Chinny. Apparently, Mom's domestic position of being authoritative can be well reflected from her son, and the two dogs clarified Reggie's mental activities which greatly showed his weak and feeble personality.

Moreover, equal attention should be given to the scissors which the Mom used. When her son, Reggie, was going to leave home, she was using the scissors to snap to head of the dead flowers, and she stopped at the sight of him. There were totally two "snip" the voice that was made by the scissors. "Snip”. "Off came a head. Reggie 
almost jumped” (Mansfield, 2008, p. 232). The first voice was followed by Reggie’s vague answer to his Mom’s question, and it showed he was jumpy about not telling her the truth. "snip, went the scissors again. Poor little beggars; they were getting it" (Mansfield, 2008, p. 233), the second "snip” revealed that Reggie sympathized with the cut-down flowers. In other words, it also showed Reggie's suffering from the experience of the years' living with Mom. He regarded the flowers which were cut by Mom as self. In the past years, his life was always trimmed by his powerful Mom, and like the sharp scissors to flowers, Mom could easily control Reggie. Though he realized the bitter facts, he could not revolt against his mighty Mom but tolerate her control, which greatly showed the Mom's domestic position of being authoritative. Within the vivid description of the scissors, an image of a woman, Mom, with domestic authority, was portrayed who definitely represented the feminist thoughts of women.

\section{Spiritual Rebellion of Mrs. Dove}

Besides the mighty and authority mom, another female character should be given equal attention—Mrs. Dove. This story was written in 1920s, at that time, great social changes had been brought to England, and women started to struggle for their own rights. "Many feminist movements offered Mansfield the materials and sources to depict the images of women, which on the other hand, furthered the development of feminism” (HE, 2011, p. 3).

Feminism reproaches the oppression that women in the patriarchal society suffer from their inferior position, thus, it focuses on the relationship on sex and law. "Seeking the lawful and political concern for women's rights to be human and to be women, feminism takes equality and difference as its theory center domain” (TIAN, 2006, p. 5). The origin of feminism can be traced back as far as Mary Wollstonecraft's "The Vindication of the Rights of Women" (Wollstonecraft, 1992, p. 125) which states women's equal rights with men in a public and brave way. Feminism is shaped by women's liberation movements and develops with it. The first wave of the women's movement began in the second half of the 19th century, focusing on gaining women's suffrage, and reached its height in the 20th century. The suffrage movement was not simply a political campaign but a profound rebellion against oppression and inequality. Under such circumstances, increasing women became aware of their inferior status domestically and socially. These new women not only organized numerous political movements for women's right to vote, but also produced a vast quantity of writing, from political pamphlet to novels, manifesting their own experience as women and calling for their equal rights with men. Among them, "Virginia Woolf was obviously the most one, indisputably considered as a feminist pioneer” (WU, 2005, p. 7).

In Mr. and Mrs. Dove, Mrs. Dove, which was one of Anne's two pet doves, always walked ahead of Mr. Dove. When depicting them, Mansfield used some accurate verbs to show the different positions of the two, which, in other word, emerged the distinctive relationship between Anne and Reggie.

After a few talking with Reggie, Anne asked him to say goodbye to her pet doves. As described, the two doves "one was always in front of the other, one ran forward, uttering a little cry, and the other followed, solemnly bowing and bowing” (Mansfield, 2008, p. 234). The one in front was the Mrs. Dove, she was followed by Mr. Dove. The two verbs "followed" and "bow" manifest that Mr. Dove was occupying a lower position and he was in a passive place, while Mrs. Dove held the right to control him. Unlike the traditional females, Mrs. Dove's spiritual rebellion against the women's inferior position led her to walk ahead of her spouse. As a result, Anne was a well-educated girl with pioneering thoughts, and as for Reggie, he was a weak, dependent and 
indecisive man who was always followed Mom's order. If they lived together, they wouldn't be happy, instead, they would be Mr. and Mrs. Dove. Thus, there is no doubt that Reggie could be the one who was always walking behind, bowing and bowing. Apparently, there would exist no equality in their marriage. Mrs. Dove set a good example for Anne, and in a wider sense, it universally inspired and stimulated all the women at that time. Mansfield emphasized the awakening awareness of women that women were not inferior to men any more, and the time when men enslaved women had already gone.

\section{Pioneering Independence of Anne}

Besides the authoritative Mom and the rebelling Mrs. Dove, there also existed another pioneering female who held anti-tradition thoughts-Anne. Anne's character was built by many repetitions, such as repeating verb and repeating conversational structure. By means of them, the independence of the girl with unusual thoughts was vividly presented in Mr. and Mrs. Dove.

"laugh" is repeatedly used in the story. During Reggie's visiting, Anne laughed at him many times, which clarified the special relationship between Reggie and Anne. As an upper-class woman, Anne thought her position was obviously not in consistent with Reggie's. What is worse, Reggie's weak personality was so much so that she thought he was the same as "Mr. Dove" who was always following his spouse. Since these ideas had sprouted in Anne's mind, she laughed at him at the very first moment they met. Tracing back to the day when Reggie went to her house to say goodbye, Anne couldn't help laughing at him either. Seeing Reggie's overcautious face, "she laughed outright” (Mansfield, 2008, p. 234), when Reggie tore his secret out of himself and offered to her, she objected him and laughed at him because of seeing his funny bow-tie. Knowing Anne's feeling about him, Reggie was too frustrated to be her home, and he was determined to leave. However, he was easily stopped by Anne's few words. Looking at his puzzled and timid look, she gave a little laugh again. The final laugh conveyed two important messages. For one thing, Reggie's habitual reaction was really hilarious to Anne, for another, Anne was satisfied with her control over Reggie, as Mrs. Dove did to Mr. Dove, she could easily get command of Reggie, thus, she was really overjoyed that she would be the master of their marriage. The repeating use of "laugh" undoubtedly revealed that Anne had reversed the man's traditional authority, that is, being more independent instead of being attached to men. What is more, she set her own position by herself.

Apart from the repeated use of "laugh" mentioned above, the repeating conversational structure strengthened Anne’s personality as well. During the talking with Reggie, Anne used many imperative sentences. Imperative sentence is always used by powerful people to show their tones like order, suggestion, demand, etc. When talking to Reggie, some sentences given by Anne such as "Do sit down” (Mansfield, 2008, p. 234), “and smoke, won’t you?” (Mansfield, 2008, p. 234), “come and say goodbye to my doves” (Mansfield, 2008, p. 234), and the final words of the story "come back, Mr. dove” (Mansfield, 2008, p. 238), which obviously expressed Anne's personality of being independent and dominating others. Thus, it revealed her higher position by comparison with Reggie's. Because of being an upper-class woman, Anne showed the great desire to be the leader so that she strived to hold the right to control their conversations. While things are quite different from Reggie, he offered many incomplete and intermittent sentences. When he arrived at Anne's home and saw her, he said “As a matter of fact, I've only come...to say good-bye” (Mansfield, 2008, p. 234). He stammered and he was hesitant to tell the real purpose of the visit. Because of lacking of confidence, he didn't go straight to tell his heart 
out, and he replaced the proposal with the good-bye. What is more, in the later conversation, when Reggie mentioned his unwillingness of working in Africa and he explained "I could stand any amount of it, used to like it even. It's the idea of...” (Mansfield, 2008, p. 234). Though the key information was missed, obviously, what he really could not stand was the separation between Anne and him. However, he was too timid to complete it, thus, the unutterable words strengthened his weakness. Due to the different family backgrounds, Reggie was brought up by his widow Mom, obeying almost all the rules made by her. To some extent, he was a mommy boy with an indecisive and dependent character. As a result, their ways of talking differ from each other sharply.

By the repetition of the verb and the conversational structure, Anne was characterized vividly from the perspective of feminism. Anne, as a feminist representative, had realized that woman was not inferior to man anymore and started to seek her own rights. There is no denying that Anne's pioneering thoughts and her independence definitely represented the feminist thoughts at her time.

\section{Conclusion}

Mr. and Mrs. Dove was created in Britain in 1920s, and it's time when the modern industrial civilization secured a further development. There was a growing number of the awakening women in the western countries. Though they had material abundance, they had spiritual poverty with empty minds and hollow spirits. In the meanwhile, they were unwilling to be the puppet of their husbands and the victim of the family. Thus, they strived to escape from the prison that was chained by tradition, and began to struggle for their self-identity and dignity. Under such circumstance, Mansfield showed her feminist thoughts by some of her works, Mr. and Mrs. Dove was one of those representative works. She successfully conveyed her advanced thoughts by the three female characters. Firstly, the authoritative Mom who cared a lot about her son and her whole family, even though her son had already became an adult. However, she was the real authority of her family. Secondly, the rebellion Mrs. Dove, who was walking ahead, controlled its spouse, which revolted against the traditional rules. Undoubtedly, Mrs. Dove represented the awakening awareness of women. Thirdly, the independent Anne, unlike the other traditional woman, held different attitude towards marriage in that she attached great importance to the implementation of self-value. Mansfield's works were the reflection of the social changes, and her advanced thoughts cleared the way for further feminism exploring in the literary field. Moreover, the feminist thoughts in her stories greatly shocked the traditional patriarchy and obviously stimulated the modern women's strong desire for their thorough liberation.

\section{References}

GUI, Y. Q. (1985). Selected reading in English and American literature. Beijing: Translation Company Press.

HE, D. L. (August, 2011). Katherine Mansfield: A special feminist—By a close reading of A Dill Pickle. Oversea English, 3.

Mansfield, K. (2008). The collected stories of Katherine. USA: Penguin Books Press.

Margaret, F. (1999). Women in the nineteenth century. Beijing: Foreign Language Teaching and Research Press.

Wollstonecraft, M. (1992). A vindication of the right of woman \& the subjection of woman. UK: Everyman's Library.

Raman, S. (2004). A reader's guide to contemporary literary theory. Beijing: Foreign Language Teaching and Research Press.

De Beauvoir, S. (1989). The second sex. USA: Vintage Press.

TIAN, L. (2006). The distinction, rethinking and surpass of feminism. Jilin: Jilin University Press.

Woolf, V. (2002). A room of one's own. London: Penguin Classic Press.

WU, D.(2005) Katherine Mansfield: A feminist pioneer. Anhui: Anhui University Press.

ZHANG, S. Y. (2005). History of Western literature in 20th century. Beijing: Peking University Press. 